NOVEL BEGINNINGS 

PATRICIA MEYER SPACKS

\section{Novel Beginnings}

EXPERIMENTS IN EIGHTEENTH-CENTURY

ENGLISH FICTION 
Yale Guides to English Literature

Yale Guides to English Literature survey topics in English literature from Beowulf to the contemporary scene. Each volume of the series is intended for students and general readers.

Published with assistance from the Annie Burr Lewis Fund and the Mary Cady Tew Memorial Fund.

Copyright (C) 2006 by Patricia M. Spacks.

All rights reserved.

This book may not be reproduced, in whole or in part, including illustrations, in any form (beyond that copying permitted by Sections Io7 and Io8 of the U.S. Copyright Law and except by reviewers for the public press), without written permission from the publishers.

Printed in the United States of America.

Library of Congress Cataloging-in-Publication Data

Spacks, Patricia Ann Meyer.

Novel beginnings : experiments in eighteenth-century English fiction / Patricia Meyer Spacks.

p. $\quad \mathrm{cm}$. - (Yale guides to English literature)

Includes bibliographical references and index.

ISBN-I3: 978-0-300-IIO3I-9 (alk. paper)

ISBN-IO: 0-300-IIO3I-6 (alk. paper)

I. English fiction-I8th century-History and criticism. 2. Experimental fiction, EnglishHistory and criticism. 3. Literary form-History—I8th century. I. Title. II. Series.

PR858.E982S66 2006

$823^{\prime} \cdot 509-\mathrm{dc} 22$

2005024209

A catalogue record for this book is available from the British Library.

The paper in this book meets the guidelines for permanence and durability of the Committee on Production Guidelines for Book Longevity of the Council on Library Resources.

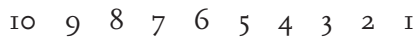


For Aubrey Williams

Blest with a Taste exact, yet unconfin'd;

A Knowledge both of Books and Humankind;

Gen'rous Converse; a Soul exempt from Pride;

And Love to Praise, with Reason on his Side. 
